\title{
Analysis of Nutritional and Fatty Acid Composition of a Bowl of Meatball Soup in Malang, Indonesia
}

\author{
Rina Rifqie Mariana ${ }^{1 *}$, Nony Aji Sunaryo ${ }^{2}$
}

\author{
${ }^{1,2}$ Culinary Education Study Program. Universitas Negeri Malang. Semarang 5 Malang, East Java \\ *Corresponding Author: rina.rifqie.ft@um.ac.id
}

\begin{abstract}
This study aimed at analysing the nutritional and fatty acid composition of a bowl of meatball soup sold by 5 bakso Malang restaurants in Malang, Indonesia. The analysis was performed according to the instructions for food and beverage testing outlined in the Indonesian National Standard (SNI) 01-2891-1992. The results showed that the average nutritional value of a bowl of meatball soup consists of protein: $52.42-78.97 \mathrm{~g}$, fat: 33.16-59.22g, water: 193.57- $285.61 \mathrm{~g}$, ash: 14.76-24.15 g, carbohydrate: 73.84-84.23g, iron: 12.38-19.30 $\mathrm{mg}$, calcium: $262.91-388 \mathrm{mg}$. Also, the level of unsaturated fatty acids is higher than saturated fatty acids with a ratio of 1.3:1.
\end{abstract}

Keywords: nutrition, fatty acid, bakso Malang

\section{INTRODUCTION}

Bakso or meatball soup is one of the most popular dishes from Malang city, East Java, Indonesia. It is a must-eat food when travelling to the city. Bakso Malang is available in many high-end restaurants and also sold by street vendors in food pushcarts or food stalls. There are several famous bakso Malang restaurant brands, one of which has expanded rapidly across the country by opening 200 franchises spread in 15 provinces [1]. According to [1], bakso is the most sold one-dish meal in Malang city (525 street food vendors). A bowl of bakso has been an all-time favourite not only due to its scrumptious taste but also owing to its variety of complementary ingredients. A typical bakso Malang consists of two kinds of meatballs, i.e. bakso halus (smooth meatballs) and bakso kasar (tendon meatballs), fried and steamed siomay (dumplings), noodle, tofu and others; some vendors even include quail eggs, kikil (cow skin) and others. With all these ingredients, a bowl of bakso is estimated to have a high nutritional content and therefore can serve as a substitute for a complete meal which usually consists of rice, side dishes and vegetables. As stated by [2], proteins of animal origin, such as those in meat, have a greater biological value than proteins from plant sources because the plantbased proteins lack some of the essential amino acids. Consumption of processed meat can also stimulate appetite and create a feeling of fullness.

In addition to taste, other aspects like nutrition and safety are key considerations to consumers in choosing their food. As stated by [3], consumers' preferences for foods are influenced by several factors. Besides the social and cultural factors, food quality including flavour, taste and appearance, also have a profound influence on the consumers' decisions in purchasing foods [4]. Organic food, local food and highly nutritious food are not only gaining popularity in developed countries but also in developing countries such as China and India [5]. A shift in consumerism occurred because local and highly nutritious food fulfils the modern consumers' healthy lifestyle. Nowadays, more modern consumers prefer healthy and sustainable food choices. Consumers in some developing countries are beginning to show interest in understanding the entire process of food production to ensure food safety [6, p. 2012]. According to [7], most urban people nowadays want to develop and engage in the healthy eating behaviour.

Bakso Malang as the city's prime culinary trademark will be more likely to be accepted by people across Indonesia and even the world if efforts to build trust and confidence among customers can be made more effectively. As stated by [8], local food and sustainable tourism can be developed by engaging with regional specialities, providing comfortable places and creating a positive image to tourists. The growth of tourism has an impact on sustainable economic, environmental and social-cultural growth [9]; [10]. The high incidence of food-related illnesses has created public alarm that makes consumers aware of the importance of food nutritional quality and safety [11]; [12].

Doubts have arisen over the safety of bakso products because some research findings have revealed that many marketed meatball products contain additives that endanger human health such as borax, formaldehyde, and other harmful substances. Previous studies found that many bakso producers in Medan, Semarang, Yogyakarta and some other cities in Indonesia use borax and formaldehyde as an emulsifier, exceed the maximum legal limit of using MSG and make meatballs out of poor quality ingredients. However, previous research of the author found that meatball products from the 5 most wellknown bakso Malang restaurants are free from borax and formaldehyde and contain safe amounts of MSG. This research showed that the amount of MSG in 1 portion of meatball soup in Restaurant A: $557.08 \mathrm{mg}$, Restaurant B: $834.10 \mathrm{mg}$, Restaurant C: $639.93 \mathrm{mg}$, Restaurant D: $457.02 \mathrm{mg}$ and Restaurant E: $703.82 \mathrm{mg}$. In other words, bakso sold by the 5 restaurants are safe for consumption because they do not exceed the maximum acceptable daily 
in Malang city, Indonesia. A portion of meatball soup in the five restaurants under study weighs from $217.81 \mathrm{~g}$ to $299.00 \mathrm{~g}$ and consists of smooth and tendon meatballs, steamed and fried dumplings, tofu, noodles, and $200 \mathrm{ml}$ broth.

\section{METHOD}

\section{A. Research Samples}

The samples of bakso Malang were taken from five wellknown restaurant brands in Malang. A bowl of bakso from each restaurant contained two medium-sized, smooth meatballs, one tendon meatball, tofu, steamed dumplings, two types of fried dumplings, yellow noodles and $200 \mathrm{ml}$ broth. The weight of each of the five bowls of bakso Malang is shown in Table 1.

Table 1. Volume Per Serving of Bakso Malang from Each Restaurant

\begin{tabular}{lccccc}
\hline Ingredient & Restaurant A & Restaurant B & Restaurant C & Restaurant D & Restaurant E \\
\hline Tendon meatball $(\mathrm{g})$ & 28.19 & 25.28 & 40.22 & 18.16 & 20.32 \\
Smooth meatball $(\mathrm{g})$ & 43.07 & 40.03 & 50.12 & 38.54 & 35.88 \\
Tofu $(\mathrm{g})$ & 80.17 & 63.71 & 38.63 & 45.60 & 62.66 \\
Noodle (g) & 45.43 & 42.49 & 23.92 & 55.22 & 40.13 \\
Steamed dumpling $(\mathrm{g})$ & 40.03 & 45.61 & 35.59 & 36.08 & 40.19 \\
$\begin{array}{l}\text { Fried dumpling } \\
\text { (pouch-shaped) }(\mathrm{g})\end{array}$ & 20.16 & 43.12 & 42.44 & 19.60 & 28.65 \\
$\begin{array}{l}\text { Fried dumpling (round } \\
\text { shaped) }(\mathrm{g})\end{array}$ & 15.75 & 38.76 & 36.47 & 17.13 & 30.11 \\
\hline Total $(\mathbf{g})$ & $\mathbf{2 7 2 . 8 0}$ & $\mathbf{2 9 9 . 0 0}$ & $\mathbf{2 6 7 . 3 9}$ & $\mathbf{2 3 0 . 3 3}$ & $\mathbf{2 1 7 . 8 1}$ \\
\hline + Broth $(\mathrm{ml})$ & 200 & 200 & 200 & 200 & 200 \\
\hline
\end{tabular}

\section{B. Research Design}

The analysis of the nutritional value (protein, carbohydrate, fat, calcium (ca), iron (Fe), ash and water contents) and fatty acid composition was performed according to the instructions for food and beverage testing set forth in the Indonesian National Standard (SNI) 012891-1992 (BSN, 1992).

Table 2. Experimental Research Design

\begin{tabular}{|c|c|c|}
\hline Type of Analysis & Type of Test & Method \\
\hline \multirow{8}{*}{$\begin{array}{l}\text { Proximate } \\
\text { Analysis }\end{array}$} & Protein content analysis & Macro-Kjeldahl (AOAC) \\
\hline & $\begin{array}{c}\text { Calorie (carbohydrate) content } \\
\text { analysis }\end{array}$ & $\begin{array}{l}\text { Qualitative and quantitative analysis with } \\
\text { the principles of chromatography }\end{array}$ \\
\hline & Fat content analysis & Soxhlet extraction \\
\hline & Calcium $(\mathrm{Ca})$ content analysis & $\begin{array}{l}\text { Atomic absorption spectrophotometry } \\
\text { (AAS) }\end{array}$ \\
\hline & Iron $(\mathrm{Fe})$ content analysis & One-way ANOVA \\
\hline & Water content analysis & Oven-drying \\
\hline & Ash content analysis & Ash furnace analysis \\
\hline & Fatty acid content analysis & Chromatography \\
\hline
\end{tabular}




\section{Apparatus and Materials}

Table 3. Materials and Equipment Utilised during the Experiment

\begin{tabular}{|c|c|c|c|}
\hline No & Type of Analysis & Equipment & Material \\
\hline 1 & $\begin{array}{l}\text { Protein Content } \\
\text { Analysis }\end{array}$ & $\begin{array}{l}\text { Analytical balance, measuring } \\
\text { pipette, rubber suction cup, } \\
\text { Kjeldahl flask, destructor, fume } \\
\text { hood, distillation apparatus, } \\
\text { Erlenmeyer flask, burette, stative, } \\
\text { clamp, dropper, volumetric flask, } \\
\text { mortar \& pestle, spatula }\end{array}$ & $\begin{array}{l}\text { Concentrated } \mathrm{H}_{2} \mathrm{SO}_{4} \text { p.a., } \mathrm{Na}_{2} \mathrm{SO}_{4-} \\
\mathrm{HgO}(20: 1) \\
\mathrm{NaOH}-\mathrm{Na}_{2} \mathrm{~S}_{2} \mathrm{O}_{3} \text {, aquades, methylene } \\
\text { red, methylene blue, ethanol } 95 \% \text {, } \\
\mathrm{HCl}, \mathrm{H}_{3} \mathrm{BO}_{3} \text {. }\end{array}$ \\
\hline 2 & Fat content analysis & $\begin{array}{l}\text { Analytical balance, mortar \& pestle, } \\
\text { oven, heater, filter paper, measuring } \\
\text { cup, soxhlet extraction set, beaker, } \\
\text { desiccator }\end{array}$ & $\begin{array}{l}\text { Petroleum ether or hexane } \\
\text { Filter cloth or paper }\end{array}$ \\
\hline 3 & $\begin{array}{l}\text { Calcium content } \\
\text { analysis }\end{array}$ & $\begin{array}{l}\text { Analytical balance, measuring } \\
\text { pipette, rubber suction cup, } \\
\text { volumetric flask, test tube, cuvette, } \\
\text { spectrophotometer }\end{array}$ & $\begin{array}{l}\text { Standard } \mathrm{CaCl}_{2} \text { solution } \\
\text { Reagent test kit (calcium cell test, } \\
\text { Merck Spectroquant) } \\
\mathrm{HCl} 1 \mathrm{~N} \\
\text { Dissolve } 82.9 \mathrm{ml} \text { of concentrated } \mathrm{HCl} \\
\text { p.a in distilled water (aquades) and } \\
\text { make up to } 1000 \mathrm{ml} \text { with distilled } \\
\text { water. } \\
\mathrm{NaOH} 1 \mathrm{M} \\
\text { Dissolve } 40 \mathrm{~g} \text { of sample in aquades } \\
\text { and make up the volume to } 1000 \mathrm{ml} \\
\text { with aquades. } \\
\mathrm{H}_{2} \mathrm{SO}_{4} 0.5 \mathrm{M} \\
\text { Dissolve } 27.7 \text { ml of concentrated } \\
\mathrm{H}_{2} \mathrm{SO}_{4} \text { p.a in aquades and make up } \\
\text { the volume to } 1000 \text { ml with aquades. } \\
\text { Aquades }\end{array}$ \\
\hline 4 & $\begin{array}{l}\text { Iron content } \\
\text { analysis }\end{array}$ & $\begin{array}{l}\text { Analytical balance, measuring } \\
\text { pipette, rubber suction cup, } \\
\text { volumetric flask, test tube, cuvette, } \\
\text { spectrophotometer }\end{array}$ & $\begin{array}{l}\text { Standard } \mathrm{FeCl}_{3} \text { solution } \\
\text { Reagent test kit (iron cell test, Merck } \\
\text { Spectroquant) } \\
\mathrm{HCl} 1 \mathrm{~N} \\
\text { - Dissolve } 82.9 \mathrm{ml} \text { of concentrated } \\
\mathrm{HCl} \text { p.a and make up to } 1000 \mathrm{ml} \\
\text { with distilled water. } \\
\mathrm{NaOH} 1 \mathrm{M} \\
\text { - Dissolve } 40 \mathrm{~g} \text { of sample in aquades } \\
\text { and make up the volume to } 1000 \\
\text { ml with aquades. }\end{array}$ \\
\hline 5 & $\begin{array}{l}\text { Water content } \\
\text { analysis }\end{array}$ & $\begin{array}{l}\text { Weighing bottle, oven, desiccator, } \\
\text { analytical balance }\end{array}$ & Silica gel \\
\hline 6 & $\begin{array}{l}\text { Ash content } \\
\text { analysis }\end{array}$ & $\begin{array}{l}\text { Ash crucible, furnace, desiccator, } \\
\text { analytical balance }\end{array}$ & Silica gel \\
\hline 7 & $\begin{array}{l}\text { Fatty acid content } \\
\text { analysis }\end{array}$ & $\begin{array}{l}\text { Gas chromatography, analytical } \\
\text { balance, beaker, bottle with lid, } \\
\text { measuring pipette, rubber suction } \\
\text { cup, oven }\end{array}$ & $\begin{array}{l}\text { Na sulfate, hexane, acetone, ethanol, } \\
\mathrm{KOH} \text {, diethyl ether, diazomethane }\end{array}$ \\
\hline
\end{tabular}




\section{A. Nutritional Composition of One Portion of Meatball Soup and a Single Meatball of $100 \mathrm{~g}$ in 5 Restaurants of Bakso Malang}

Table 4 and 5 present the results of nutritional
alysis of one portion of meatball soup and a single meatball (100 gr) including the contents of calories, protein, fat, calcium, iron and water.

Table 4. Nutritional Composition of a Bowl of Bakso Malang Soup (Portion Size for 1 Serving)

\begin{tabular}{lccccc}
\hline $\begin{array}{c}\text { Nutritional } \\
\text { Composition }\end{array}$ & $\begin{array}{c}\text { Restaurant } \\
\text { A }\end{array}$ & $\begin{array}{c}\text { Restaurant } \\
\text { B }\end{array}$ & Restaurant C & $\begin{array}{c}\text { Restaurant } \\
\text { D }\end{array}$ & $\begin{array}{c}\text { Restaurant } \\
\text { E }\end{array}$ \\
\hline \multicolumn{1}{c}{ Volume/portion } & $272.80 \mathrm{gr}+$ & $299.00+$ & $267.39+200$ & $230.33+$ & $217.81+$ \\
& $200 \mathrm{ml}$ broth & $200 \mathrm{ml}$ broth & $200 \mathrm{ml}$ broth & $200 \mathrm{ml}$ broth & $200 \mathrm{ml} \mathrm{broth}$ \\
\hline Calorie (cal) & 1126.82 & 1255.80 & 1113.65 & 855.93 & 1088.83 \\
Protein (g) & 78.97 & 77.18 & 71.77 & 52.42 & 70.85 \\
Fat (g) & 47.38 & 59.22 & 47.76 & 33.16 & 44.73 \\
Water (g) & 261.08 & 285.61 & 253.59 & 193.57 & 242.26 \\
Ash (g) & 24.15 & 21.94 & 20.16 & 14.76 & 21.84 \\
Carbohydrate (g) & 76.38 & 84.23 & 81.25 & 73.84 & 82.99 \\
Iron (mg) & 19.30 & 18.74 & 19.12 & 12.38 & 16.94 \\
Calcium (mg) & 381.24 & 388.58 & 374.75 & 262.91 & 346.23 \\
\hline
\end{tabular}

Table 5. Nutritional Composition of a Single Meatball (100 G) of Bakso Malang

\begin{tabular}{lccccc}
\hline $\begin{array}{c}\text { Nutritional } \\
\text { Composition }\end{array}$ & Restaurant A & Restaurant B & Restaurant C & Restaurant D & Restaurant E \\
\hline Calorie (cal) & 230.92 & 237.76 & 234.68 & 232.74 & 235.33 \\
\hline Protein $(\mathrm{g})$ & 16.18 & 14.61 & 15.12 & 14.25 & 15.31 \\
\hline Fat $(\mathrm{g})$ & 9.71 & 11.21 & 10.06 & 9.02 & 9.68 \\
\hline Water $(\mathrm{g})$ & 53.50 & 54.07 & 53.44 & 52.64 & 52.36 \\
\hline Ash $(\mathrm{g})$ & 4.95 & 4.15 & 4.25 & 4.01 & 4.72 \\
\hline Carbohydrate $(\mathrm{g})$ & 15.65 & 15.95 & 17.12 & 20.08 & 17.94 \\
\hline Iron $(\mathrm{mg})$ & 3.96 & 3.55 & 4.03 & 3.36 & 3.66 \\
\hline Calcium $(\mathrm{mg})$ & 78.13 & 73.57 & 78.97 & 71.49 & 74.83 \\
\hline
\end{tabular}

Table 4 and 5 suggest that the meatball products sold by the five Bakso Malang restaurants have almost the same nutritional value in all observed nutritional parameters. The calorific value of each $100 \mathrm{~g}$ meatball ranges from 230-237 calories, while that of each bowl of meatball soup ranges from 1088 to 1255 calories.

The protein content of a $100-\mathrm{g}$ meatball in all restaurants under study is also nearly equal, i.e. 14-16 g. However, the protein content in a bowl of meatball soup (portion size for 1 serving) is slightly different. A bowl of meatball soup by Restaurant A has the highest protein content of $16.18 \mathrm{~g}$. Based on the research conducted by [15], the ratio of meat to flour used to make meatballs at Restaurant A is 70:30, while in other places the commonly used ratio of meat to flour is 60:40, hence the result above. Also, the raw materials used are fresh pre-rigour meat cuts, namely silverside. [16] explained that the right beef cuts for meatball production are topside, silverside and cube roll. These three parts have higher protein contents, the highest brightness and redness and the lowest fat content. The quality of food protein is determined by its composition of essential amino acids. Animal-based foods contain a more complete panel of amino acids than plant-based foods, therefore animal-based foods are excellent sources of protein [17]. Another contributing factor to the protein content of processed meat is the use of table salt $(\mathrm{NaCl})$ as the condiment. As found by [18], the higher the addition of $\mathrm{NaCl}$, the lower the protein level in meatballs. $\mathrm{NaCl}$ weakens the interaction between different charged groups in proteins. Chloride ion $(\mathrm{Cl}-)$ in a negatively charged groups will bind to positively charged groups of proteins and convert the total protein charge into negative, so that repulsive forces occur between filaments. The repulsive forces cause the space between the filaments to increase, giving more space to bind more water. In other words, the addition of $\mathrm{NaCl}$ results in a decrease in protein content but a rise in water content. In addition, factors related to the thermal processing of meat such as temperature and heating time may cause both expected and unexpected reactions [19] [20].

All of the five Bakso Malang restaurants also produce meatballs with almost the same fat content, i.e. 9-11 g in a 
temperature causes the evaporation rate to rise, allowing more water molecules in bakso to dissipate into the air. The ash content is a manifestation of mineral content in the ingredients. The ash content of a 100-g meatball in all restaurants under study is almost the same, i.e. 4.01-4.95 g. However, the ash content in a bowl of meatball soup is slightly different in each bakso Malang restaurant. The meatball soup by Restaurant D contains the lowest ash, which is $14.76 \mathrm{~g}$ per portion. The other four restaurants sell meatball soup with an ash level of 20-24 g per portion. According to [24], the higher the amount of $\mathrm{NaCl}$ added, the higher the ash content produced. It occurs because salt is an inorganic material which is a constituent component of ash. Most food ingredients consist of organic material and water (96\%), and the rest is mineral elements [25].

The iron $(\mathrm{Fe})$ content of a bowl of meatball soup in all restaurants under study is nearly the same, i.e. 12.38-19.3 $\mathrm{g}$, while the calcium content $(\mathrm{Ca})$ ranges from 262.91 to $388.58 \mathrm{~g}$

Based on the above findings, the nutritional composition of a bowl of bakso Malang can serve as an alternative to lunch meals with a fairly rich in nutrients. The nutritional composition of 1 portion of bakso Malang compared to daily nutritional requirements for adults is presented in Table 6.

Table 6. Comparison between Nutritional Composition of One Portion of Bakso Malang and Daily Nutritional Requirements for Adults Based on Recommended Dietary Allowances or Angka Kecukupan Gizi (AKG) [26]; [27]

\begin{tabular}{|l|c|l|}
\hline $\begin{array}{c}\text { Nutritional } \\
\text { Composition }\end{array}$ & A Portion of Bakso Malang & $\begin{array}{c}\text { Daily Nutritional Requirements for Adults } \\
\text { Based on Recommended Dietary Allowances } \\
\text { (AKG) [26] }\end{array}$ \\
\hline Energy/Calorie (Kcal) & $855.93-1255.80$ & P: $1700-2200 ; \mathrm{L}: 2400-2800$ \\
\hline Protein (gr) & $52.42-78.97$ & P: $48-62 ; \mathrm{L}: 55-66$ \\
\hline Fat (gr) & $36.16-59.22$ & $10-25 \%$ of calorie needs $(60 \mathrm{~g} / \mathrm{day})$ \\
\hline Calcium $(\mathrm{mg})$ & $374.75-388.58$ & P: $600 ; \mathrm{L}: 500$ \\
\hline Iron $(\mathrm{mg})$ & $12.38-19.30$ & $26 \mathrm{mg}$ P/L \\
\hline Water $(\mathrm{g})$ & $193.57-261.08$ & $2000 \mathrm{ml}-2500 \mathrm{ml}$ \\
\hline Carbohydrate $(\mathrm{g})$ & $73.84-84.23$ & $60-70 \%$ of calorie needs \\
\hline
\end{tabular}

Table 6 shows that the nutritional value of a bowl of bakso Malang is adequate to meet nutritional needs for 1 lunch meal; Indonesians generally eat 3 meals a day, i.e. breakfast, lunch and dinner. However, the fat content of 1 bowl of meatball soup by Restaurant B is $59.22 \mathrm{gr}$, which exceeds the recommended daily fat intake. According to (Organization, Organization, \& Organization, 2013) and
(Council, n.d.), the total fat content of the diet should be no more than $60 \mathrm{~g}$ or $30 \%$ of total daily calories. The fat content of meatball soup mainly comes from the beef bone broth. Beef bones contain approximately $50 \%$ water, $50 \%$ marrow and $96 \%$ fat [28]. On top of that, other complementary ingredients in bakso such as fried dumplings contribute to the high-fat content. 


\section{B. Fatty Acid Composition of a Single Meatball of $100 \mathrm{~g}$ in 5 Restaurants of}

\section{Bakso Malang}

The fatty acid composition of a 100 -g meatball by 5 bakso Malang restaurants is presented in Table 6.

Table 7 Fatty Acid Composition of a Single Meatball of $100 \mathrm{~g}$ in 5 Restaurants of Bakso Malang

\begin{tabular}{|c|c|c|c|c|c|c|}
\hline \multicolumn{2}{|c|}{ Fatty Acid Composition } & $\begin{array}{c}\text { Restaurant } \\
\text { A } \\
\end{array}$ & $\begin{array}{c}\text { Restaurant } \\
\text { B } \\
\end{array}$ & $\begin{array}{c}\text { Restaurant } \\
\text { C }\end{array}$ & $\begin{array}{c}\text { Restaurant } \\
\text { D } \\
\end{array}$ & $\begin{array}{c}\text { Restaurant } \\
\text { E }\end{array}$ \\
\hline C14:0 & Myristic acid & 240.94 & 279.70 & 248.16 & 225.47 & 238,47 \\
\hline C16:0 & Palmitic acid & 2395.58 & 2764.52 & 2471.97 & 2221.50 & 2371,31 \\
\hline C16:1 (n-7) & Palmitoleic acid & 453.18 & 505.86 & 467.47 & 420.12 & 443,20 \\
\hline C18:0 & Stearic acid & 1539.96 & 1769.65 & 1589.50 & 1429.27 & 1522.45 \\
\hline C18:1 (n-9) & trans Elaidic acid & 241.30 & 286.65 & 258.23 & 228.26 & 246.39 \\
\hline C18:1 (n-9) & cis Oleic acid & 3900.96 & 4508.40 & 4001.15 & 3625.85 & 3876.45 \\
\hline C18:1 (n-7) & trans Vaccenic acid & 152.02 & 170.73 & 161.41 & 142.51 & 150.14 \\
\hline C18:2 (n-6) & Linoleic acid & 307.30 & 349.98 & 315.35 & 285.23 & 304.92 \\
\hline C18:6 (n-3) & $\gamma$ Linolenic acid & 2.87 & 3.28 & 3.27 & 2.71 & 2.89 \\
\hline $\mathrm{C} 18: 3(\mathrm{n}-3)$ & $\alpha$ Linolenic acid & 144.37 & 163.41 & 151.75 & 134.47 & 141.92 \\
\hline C20:2 (n-6) & Eicosadienoic acid & 3.03 & 3.44 & 2.88 & 2.63 & 2.97 \\
\hline C20:3 (n-6) & $\begin{array}{l}\text { Dihomo } \gamma \text { linolenic } \\
\text { acid }\end{array}$ & 37.57 & 41.67 & 39.11 & 35.17 & 38.11 \\
\hline C20:3 (n-3) & Eicosatrienoic acid & 3.94 & 4.26 & 4.01 & 3.67 & 3.87 \\
\hline $\mathrm{C} 20: 4(\mathrm{n}-3)$ & Eicosatetraenoic acid & 115.71 & 133.48 & 115.64 & 106.12 & 115.51 \\
\hline C20:4 (n-6) & Arachidonic acid & 29.18 & 31.55 & 30.90 & 26.15 & 29.12 \\
\hline C20:5 (n-3) & $\begin{array}{l}\text { Eicosapentaenoic } \\
\text { acid }\end{array}$ & 78.03 & 89.76 & 80.73 & 72.59 & 76.54 \\
\hline C22:4 (n-6) & $\begin{array}{l}\text { Docosatetraenoic } \\
\text { acid }\end{array}$ & 9.42 & 11.20 & 10.41 & 8.76 & 9.38 \\
\hline C22:6 (n-3) & $\begin{array}{l}\text { Docosahexaenoic } \\
\text { acid }\end{array}$ & 9.28 & 11.22 & 9.87 & 9.06 & 9.50 \\
\hline \multicolumn{2}{|c|}{ Saturated fatty acid (mg) } & 4176.49 & 4813.86 & 4309.64 & 3876.25 & 4132.24 \\
\hline \multicolumn{2}{|c|}{ Unaturated fatty acid (mg) } & 5488.16 & 6314.88 & 5652.20 & 5103.32 & 5450.90 \\
\hline \multicolumn{2}{|c|}{ Monounsaturated fatty acid (mg) } & 4747.45 & 5471.64 & 4888.27 & 4416.75 & 4716.18 \\
\hline \multicolumn{2}{|c|}{ Polyunsaturated fatty acid (mg) } & 740.71 & 843.24 & 763.93 & 686.57 & 734.72 \\
\hline \multicolumn{2}{|c|}{$\begin{array}{l}\text { Ratio of saturated fatty acid to } \\
\text { unsaturated fatty acid }\end{array}$} & $1: 1.31$ & $1: 1.31$ & $1: 1.31$ & $1: 1.32$ & $1: 1.32$ \\
\hline \multicolumn{2}{|c|}{$\begin{array}{l}\text { Ratio of monosaturated fatty acid to } \\
\text { polysaturated fatty acid }\end{array}$} & 1: 0.16 & $1: 0.15$ & $1: 0.16$ & $1: 0.16$ & $1: 0.16$ \\
\hline \multicolumn{2}{|c|}{ Trans unsaturated fatty acid (mg) } & 393.31 & 457.38 & 419.65 & 370.78 & 396.53 \\
\hline
\end{tabular}

Table 7 shows that the fatty acid composition of a single meatball of $100 \mathrm{~g}$ produced by all restaurants under study is nearly the same. The fatty acids contained in a meatball include saturated fatty acids and unsaturated fatty acids. The saturated fatty acids are myristic acid, palmitic acid, stearic acid. The monounsaturated fatty acids include palmitoleic acid, trans elaidic acid, cis oleic acid, trans vaccenic acid. The polyunsaturated fatty acids are linoleic acid, $\gamma$ linolenic acid, $\alpha$ linolenic acid, eicosadienoic acid, dihomo $\gamma$ linolenic acid, eicosatrienoic acid, eicosatetraenoic acid, arachidonic acid, eicosapentaenoic acid, docosatetraenoic acid and docosahexaenoic acid.

The level of unsaturated fatty acids is slightly higher than saturated fatty acids in all meatball samples. The ratio of saturated fatty acids to unsaturated fatty acids is $1: 1.3$. The amount of monounsaturated fatty acids is larger than polyunsaturated fatty acids in all meatball samples. The ratio of monounsaturated fatty acids to polyunsaturated fatty acids is 1:0.1. According to [29], trans fats are considered more harmful than saturated fats because saturated fats only raise LDL cholesterol but do not affect HDL cholesterol. Epidemiological studies have found that high-fat foods are closely linked to colon cancer and breast cancer. Low-fat and high-fibre intake such as in the vegetarian diet can reduce the number of cancer cases [30]. Also, high consumption of saturated fats causes the liver to produce large amounts of LDL cholesterol which increases the chance of having heart disease and also results in an increase in blood cholesterol levels which is a major risk factor for thrombosis [31]. Obesity is also always associated with the consumption of foods high in saturated fats or calorie content [32]. The secondary products of the oxidation of polyunsaturated fatty acids, particularly volatile aldehydes and ketones, influence the 
taste and odour of meat and processed meat products by degradation [33]. There have been some restrictions on meat intake due to the saturated fat, cholesterol and salt contents and their relationship to certain types of cancer [34]. Several studies have led us to the conclusion that the tolerable upper limit of trans fatty acid intake is about $2 \%$ of the number of total calories. The amount of trans unsaturated fatty acids in a 100-gr meatball produced by the 5 bakso Malang restaurants ranges from 370.78 to $457.38 \mathrm{mg}$.

\section{CONCLUSIONS}

This research has highlighted the following findings. 1) The portion of meatball soup in the 5 most famous bakso Malang restaurants can serve as a substitute for main course meal since its nutritional composition (calorie, protein, fat, carbohydrate, water, iron and ash contents) has satisfied the daily nutritional requirements for adults. However, the fat content of 1 bowl of meatball soup by Restaurant B is 59.22 gr, which exceeds the recommended daily fat intake which should be no more than $60 \mathrm{~g}$ or $30 \%$ of total daily calories. (2) The fatty acids contained in a meatball include saturated fatty acids and unsaturated fatty acids with a ratio of $1: 1.3$. The ratio of monounsaturated fatty acids to polyunsaturated fatty acids is $1: 0.1$.

\section{REFERENCES}

[1] R. R. Mariana, L. Hidayati, and S. Sukopitojo, "Consumer Preferences On 'Bakso Malang'Indonesia," presented at the 1st International Conference on Social, Applied Science and Technology in Home Economics (ICONHOMECS 2017), 2017.

[2] J. P. Kerry, J. F. Kerry, and D. Ledward, Eds., Meat Processing: Improving Quality, 1 edition. Boca Raton u.a. CRC Press: Woodhead Publishing, 2002.

[3] L. J. Harper and L. J. Harper, "Pangan, gizi dan pertanian / Laura J. Harper, Brady J. Deaton, Judy A. Driskel; penerjemah Suhardjo, Pangan, gizi dan pertanian / Laura J. Harper, Brady J. Deaton, Judy A. Driskel; penerjemah Suhardjo," 1. PERTANIAN DAN PANGAN $<B R>2$. PERTANIAN DAN GIZI,Pangan, gizi dan pertanian / Laura J. Harper, Brady J. Deaton, Judy A. Driskel; penerjemah Suhardjo, Pangan, gizi dan pertanian / Laura J. Harper, Brady J. Deaton, Judy A. Driskel; penerjemah Suhardjo, vol. 1986, no. 1986, pp. 1-99, 1986.

[4] J. Rana and J. Paul, "Consumer behavior and purchase intention for organic food: A review and research agenda," Journal of Retailing and Consumer Services, vol. 38, pp. 157-165, Sep. 2017.

[5] J. Patel, A. Modi, and J. Paul, "Proenvironmental behavior and socio-demographic factors in an emerging market," Asian J Bus Ethics, vol. 6, no. 2, pp. 189-214, Dec. 2017.

[6] S. A. Trivette, "Farm-to-Fork: Understanding Locally-Oriented Farm-to-Vendor Food Systems:
Access, Boundaries, and Power-Relations," p. 212.

[7] K. E. Thompson, S. Baker, K. Huntley, and J. Engelken, "Mapping the values driving organic food choice: Germany vs the UK," European Journal of Marketing, vol. 38, no. 8, pp. 9951012, Aug. 2004.

[8] R. Sims, "Food, place and authenticity: local food and the sustainable tourism experience," Journal of Sustainable Tourism, vol. 17, no. 3, pp. 321-336, May 2009.

[9] P. Boniface, Tasting Tourism: Travelling for Food and Drink. Burlington, VT: Routledge, 2003.

[10] B. Ilbery, C. Morris, H. Buller, D. Maye, and M. Kneafsey, "Product, Process and Place: An Examination of Food Marketing and Labelling Schemes in Europe and North America," European Urban and Regional Studies, vol. 12, no. 2, pp. 116-132, Apr. 2005.

[11] K. Menrad, "Market and marketing of functional food in Europe," Journal of Food Engineering, vol. 56, no. 2, pp. 181-188, Feb. 2003.

[12] M. B. Roberfroid, "Global view on functional foods: European perspectives," British Journal of Nutrition, vol. 88, no. S2, pp. S133-S138, Nov. 2002.

[13] S. N. Indonesia, "Batas maksimum cemaran mikroba dalam pangan," Jakarta: Badan Standarisasi Nasional, 2009.

[14] E. W\$^1\$sowicz et al., "Oxidation of lipids in food," Pol J Food Nutr Sci, vol. 13, pp. 87-100, 2004.

[15] R. Rifqie Mariana, L. Hidayati, and S. Soekopitojo, "Implementing the HACCP system to the production of Bakso Malang-Indonesia," Journal of Culinary Science \& Technology, pp. 1-22, 2018.

[16] Y. Ariansah, "Sifat Fisik dan Organoleptik Bakso Daging Itik Dengan dan Tanpa Kulit dengan Penambahan Tepung Daun Beluntas (Pluchea Indica L.) dalam Pakan," 2008.

[17] M. J. Gibney, H. H. Vorster, and F. J. Kok, Introduction to human nutrition. Blackwell Science Oxford, 2002.

[18] H. S. Arief, Y. B. Pramono, and V. P. Bintoro, "PENGARUH EDIBLE COATING DENGAN KONSENTRASI BERBEDA TERHADAP KADAR PROTEIN, DAYA IKAT AIR DAN AKTIVITAS AIR BAKSO SAPI SELAMA MASA PENYIMPANAN," Animal Agriculture Journal, vol. 1, no. 2, pp. 100-108, 2012.

[19] Abdullah et al., "Factors affecting household food security in rural northern hinterland of Pakistan," Journal of the Saudi Society of Agricultural Sciences, May 2017.

[20] A. S. Hassan et al., "Proximate and mineral compositions of local Kuwaiti fast foods," Ecology of Food and Nutrition, vol. 26, no. 1, pp. 37-45, Jul. 1991.

[21] G. Pramuditya and S. S. Yuwono, "PENENTUAN ATRIBUT MUTU TEKSTUR 
BAKSO SEBAGAI SYARAT TAMBAHAN DALAM SNI DAN PENGARUH LAMA PEMANASAN TERHADAP TEKSTUR BAKSO [IN PRESS OKTOBER 2014]," Jurnal Pangan dan Agroindustri, vol. 2, no. 4, pp. 200209, 2014.

[22] R. Su. Sunarlim and S. Usmiati, "Karakteristik Daging Kambing dengan Perendaman Enzim Papain," JITV, vol. 19, no. 2, 2014.

[23] D. Sundari, A. Almasyhuri, and A. Lamid, "Pengaruh proses pemasakan terhadap komposisi zat gizi bahan pangan sumber protein," Media Penelitian dan Pengembangan Kesehatan, vol. 25, no. 4, pp. 235-242, 2015.

[24] O. Mega, "Pengaruh Leaching terhadap Komposisi Nutrisi Bakso Itik Talang Benih," Jurnal Sain Peternakan Indonesia, vol. 4, no. 1, pp. 51-56, 2009.

[25] F. G. Winarno, Naskah akademis keamanan pangan. Institut Pertanian Bogor, 1997.

[26] A. K. Gizi, "Tabel Angka Kecukupan Gizi 2013 bagi Orang Indonesia," Tersedia dalam: http://gizi. depkes. go. id [Diakses tanggal 15 Oktober 2015], 2013.

[27] W. H. Organization, W. H. Organization, and W. H. Organization, "Geneva: WHO; 2010," Global recommendations on physical activity for health, 2013.

[28] S. Septimus, D. G. James, and G. Robert, Anatomy of The Domestic Animal. Mc Graww Hill, New York, 1961.
[29] D. Mozaffarian, M. B. Katan, A. Ascherio, M. J. Stampfer, and W. C. Willett, "Trans fatty acids and cardiovascular disease," N. Engl. J. Med., vol. 354, no. 15, pp. 1601-1613, Apr. 2006.

[30] S. Yu-Poth et al., "Lowering dietary saturated fat and total fat reduces the oxidative susceptibility of LDL in healthy men and women," J. Nutr., vol. 130, no. 9, pp. 2228-2237, Sep. 2000.

[31] R. A. D. Sartika, "PENGARUH SUHU DAN LAMA PROSES MENGGORENG (DEEP FRYING) TERHADAP PEMBENTUKAN ASAM LEMAK TRANS," Makara Journal of Science, Oct. 2010.

[32] N. Hoogerbrugge, R. van Domburg, E. van der Zwet, M. van Kemenade, A. Bootsma, and M. L. Simoons, "High fat intake in hyperlipidaemic patients is related to male gender, smoking, alcohol intake and obesity," The Netherlands Journal of Medicine, vol. 59, no. 1, pp. 16-22, Jul. 2001.

[33] M. Gantner et al., "Antioxidant effect of sage (Salvia officinalis L.) extract on turkey meatballs packed in cold modified atmosphere," CyTA Journal of Food, vol. 16, no. 1, pp. 628-636, Jan. 2018.

[34] A. J. Cross, M. F. Leitzmann, M. H. Gail, A. R. Hollenbeck, A. Schatzkin, and R. Sinha, "A Prospective Study of Red and Processed Meat Intake in Relation to Cancer Risk," PLOS Medicine, vol. 4, no. 12, p. e325, Dec. 2007. 